\title{
Dekomposisi Perubahan Ketimpangan di Indonesia Tahun 2005-
} 2014

\author{
Ananda Dellina Putri ${ }^{1}$, Teguh Dartanto ${ }^{2}$ \\ 1. Program Pascasarjana Ilmu Ekonomi, Universitas Indonesia, Indonesia \\ 2. Program Pascasarjana Ilmu Ekonomi, Universitas Indonesia, Indonesia \\ E-mail: anandadellina@gmail.com
}

\begin{abstract}
Income inequality in Indonesia has been worse for the past ten years, therefore the right policy is really needed to reduce inequality. However, to know what is the right policy that can reduce income inequality, studies about the inequality itself is necessary. The purpose of this study is to give picture about in what condition high inequality happened and why inequality increased. The methods used are static decomposition and decomposition of changes inequality or dynamic decomposition. The result of this study show that highest inequality happened between population with different education level of household head. There was indication that education level of household head already increased, but it still did not contribute significantly to reduce inequality. Therefore to reduce inequality, Indonesian people should be supported to increase their education level.
\end{abstract}

Keywords: changes inequality; dynamic decomposition; inequality; static decomposition

\section{PENDAHULUAN}

Indonesia telah mengalami peningkatan ketimpangan pendapatan selama sepuluh tahun terakhir. Publikasi World Bank (2015) menyatakan bahwa pada tahun 2002, total konsumsi $10 \%$ penduduk terkaya setara dengan total konsumsi $42 \%$ penduduk termiskin. Kemudian pada tahun 2014 nilai konsumsi mereka meningkat menjadi setara dengan total konsumsi $54 \%$ penduduk termiskin. Lebih jauh lagi, dari tahun 2003 hingga 2010, konsumsi riil perkapita 10\% penduduk terkaya tumbuh lebih dari $6 \%$ per tahun, tetapi konsumsi perkapita $40 \%$ penduduk termiskin hanya tumbuh kurang dari $2 \%$ per tahun. Pengukuran BPS menunjukkan bahwa koefisien Gini di Indonesia telah meningkat dari 0.363 di tahun 2005 menjadi 0.41 di tahun 2011dan stabil pada nilai tersebut hingga 2014. Dibandingkan dengan negara-negara lain di Asia Tenggara, peningkatan nilai koefisien Gini di Indonesia selama dua dekade terakhir termasuk yang tertinggi. Kondisi peningkatan ketimpangan ini dikatakan berdampak pada memperlambat laju penurunan kemiskinan, memperlambat pertumbuhan ekonomi, serta menimbulkan masalah sosial. Berdasarkan survei yang dilakukan, penduduk Indonesia juga merasa bahwa ketimpangan adalah masalah yang penting dan menginginkan pemerintah untuk segera mengambil tindakan untuk mengurangi ketimpangan saat ini. Namun, untuk mengambil tindakan guna mengatasi ketimpangan tentunya diperlukan pemahaman yang baik mengenai ketimpangan 
itu sendiri. Kita perlu memahami pada kondisi apa terjadi ketimpangan dan mengapa ketimpangan meningkat.

Ketimpangan dapat terjadi antara penduduk dengan karakteristik berbeda contohnya antara penduduk dengan tingkat pendidikan yang berbeda, antara penduduk di desa dengan di kota, antara penduduk di provinsi yang berbeda serta antara penduduk dengan status pekerjaan yang berbeda. Dibandingkan dengan pekerja berpendidikan dasar atau lebih rendah, pekerja dengan tingkat pendidikan menengah pertama memperoleh upah $20 \%$ lebih tinggi, dan pekerja dengan tingkat pendidikan menengah atas memperoleh pendapatan $40 \%$ lebih tinggi sedangkan penduduk dengan tingkat pendidikan sarjana memperoleh pendapatan dua kali lipatnya (Aji, 2015). Berdasarkan lokasinya, konsumsi per kapita populasi di kota pada tahun 2002 dua kali lipat lebih tinggi dari pada konsumsi per kapita populasi di desa (Akita dan Miyata, 2007). Data Susenas dari tahun 2011 hingga 2014 menunjukkan bahwa konsumsi perkapita penduduk di Provinsi DKI Jakarta dua kali lipat lebih tinggi dari pada konsumsi rata-rata penduduk keseluruhan dan empat kali lipat lebih tinggi dari pada konsumsi perkapita penduduk Provinsi Nusa Tenggara Timur. Serta, pendapatan pekerja formal lebih tinggi dari pendapatan rata-rata seluruh pekerja (Iryanti, 2014).

Studi terkait ketimpangan antara populasi dengan perbedaan karakteristik ini telah cukup banyak dilakukan di Indonesia. Penelitian-penelitian oleh Akita dan Lukman (1999), Akita dan Alisyahbana (2000), dan Nuraliyah (2009) dilakukan dengan menguraikan atau mendekomposisi ketimpangan pada tiap tahun, biasa disebut dekomposisi statis, setelah membagi populasi menjadi beberapa grup berdasarkan karateristik yang ingin diamati. Hasil dari penguraian ketimpangan dengan metode ini adalah 2 komponen yaitu besarnya ketimpangan yang terjadi di dalam grup (within group component) dan antar grup (beteween group component) pada populasi tersebut. Besarnya ketimpangan yang terjadi di dalam grup akan bergantung pada proporsi populasi pada masing-masing subgrup dan tingkat ketimpangan pada setiap subgrup. Sedangkan besarnya ketimpangan yang terjadi antar grup akan bergantung pada proporsi populasi pada masingmasing subgrup dan pendapatan masing-masing subgrup. Dengan metode dekomposisi statis ini, dapat diketahui pada karakteristik apakah terjadi ketimpangan yang tinggi. Namun untuk menganalisis perubahan ketimpangan yang terjadi, tidaklah cukup dengan menggunakan dekomposisi statis.

Melakukan analisis dengan nilai dekomposisi statis pada dua waktu hanya dapat menghasilkan perbedaan nilai komponen ketimpangan di dalam grup dan antar grup pada dua waktu tersebut. Padahal nilai kedua komponen ini masih bergantung pada tingkat ketimpangan, proporsi populasi dan pendapatan masingmasing subgrup. Sehingga apabila hanya menggunakan dekomposisi statis, belum dapat diketahui apakah sebenarnya perubahan tingkat ketimpangan, perubahan proporsi populasi atau perubahan pendapatan masing-masing subgrup kah yang dapat menjelaskan perubahan ketimpangan yang terjadi.

Agar dapat mengukur seberapa besar perubahan ketimpangan, perubahan proporsi populasi dan perubahan pendapatan masing-masing subgrup dapat menjelaskan perubahan ketimpangan yang terjadi, Mookherjee dan Shorrocks (1982) menurunkan formula untuk mendekomposisi nilai perubahan ketimpangan pada dua waktu, atau dekomposisi dinamis. Metode dekomposisi dinamis ini menurutnya memiliki keunggulan terutama dapat mengukur bagaimana perubahan 
proporsi populasi dan perubahan pendapatan kah yang terjadi secara simultan pada suatu rentang waktu dapat menjelaskan perubahan ketimpangan.

Karena itu, penelitian ini akan menerapkan metode dekomposisi statis untuk mengetahui pada karakteristik apakah terjadi ketimpangan tinggi serta dekomposisi dinamis sehingga untuk setiap karakteristik dapat diketahui apakah perubahan proporsi populasi atau perubahan pendapatan yang lebih dapat menjelaskan perubahan ketimpangan yang terjadi.

\section{KAJIAN PUSTAKA}

Penelitian terkait dekomposisi ketimpangan di Indonesia seperti yang dilakukan oleh Akita dan Lukman (1999), Akita dan Alisyahbana (2000), dan Nuraliyah (2009) hanya sampai melakukan dekomposisi statis. Penelitian dengan menggunakan dekomposisi statis dapat menunjukkan berapa besar ketimpangan yang terjadi antar grup pada populasi dengan berdasarkan suatu karakteristik. Hasil dari dekomposisi statis bergantung pada tingkat ketimpangan, proporsi populasi dan pendapatan masing-masing subgrup. Dengan demikian perubahan ketimpangan dapat akan dapat diuraikan menjadi faktor-faktor perubahan tingkat ketimpangan di dalam subgrup, perubahan proporsi populasi dan perubahan pendapatan masing-masing subgrup.

Mookherjee dan Shorrocks (1982) menurunkan formula untuk mendekomposisi nilai perubahan ketimpangan pada dua waktu, atau dekomposisi dinamis yang dapat mengukur seberapa besar perubahan ketimpangan, perubahan proporsi populasi dan perubahan pendapatan masing-masing subgrup dapat menjelaskan perubahan ketimpangan yang terjadi. Dengan melakukan dekomposisi dinamis, maka akan lebih memberikan gambaran terkait mengapa ketimpangan meningkat. Disinilah kontribusi penelitian ini. Penelitian ini akan menerapkan dekomposisi statis untuk mengetahui karakteristik apa yang menjadi dasar terjadinya ketimpangan pendapatan di Indonesia, dan menerapkan dekomposisi dinamis untuk mengetahui pada setiap karakteristik populasi apakah perubahan proporsi populasi atau perubahan pendapatan kah yang dapat menjelaskan perubahan ketimpangan di Indonesia.

\section{METODE}

\section{Pengukuran Ketimpangan}

Pengukuran ketimpangan umumnya dinyatakan dalam indeks Gini, indeks Theil, atau indeks Atikinson. Akan tetapi indeks Gini tidak sesuai untuk didekomposisi perubahannya karena akan sulit mengukur pengaruh perubahan populasi terhadap perubahan indeks Gini (Jurkatis dan Strehl, 2013) sedangkan indeks Atkinson tidak dapat di dekomposisi berdasarkan grup populasi (Vega dan Urrutia, 2003) Pengukuran ketimpangan yang dapat didekomposisi nilai dan perubahannya adalah indeks Theil's L atau Mean Logaritmic Deviation (MLD), (Mookherjee dan Shorrocks, 1982), maka dari itu pengukuran ketimpangan dan dekomposisi yang akan digunakan pada penelitian ini adalah berdasarkan MLD.

Pengukuran ketimpangan dengan MLD, $I_{0}$ diperoleh berdasarkan persamaan di bawah ini

$I_{0}=\frac{1}{n} \sum_{i=1}^{n} \log \left(\frac{\mu}{y_{i}}\right)$ 
dengan $\quad n$ : banyak individu atau rumah tangga;

$\mu$ :pendapatan rata-rata ;

$y_{i}$ : pendapatan individu atau rumah tangga ke $i$.

Formula ini mengukur rata-rata deviasi antara pendapatan individu dengan pendapatan rata-rata populasi dengan memberikan bobot yang sama untuk setiap individu. Hasil perhitungan akan bernilai antara 0 sampai $\infty$, dengan nilai yang semakin besar menunjukkan semakin jauhnya selisih antara pendapatan individu dengan pendapatan rata-rata atau dengan kata lain ketimpangan yang tinggi.

\section{Dekomposisi Statis}

Tujuan utama dari dekomposisi statis adalah untuk menguraikan nilai total ketimpangan atas keseluruhan populasi menjadi dua komponen, yaitu ketimpangan di dalam grup $I_{W}$ (within group atau unexplained component) dan ketimpangan antar grup $I_{B}$ (between group atau explained component).

$$
I=I_{W}+I_{B}
$$

Misalkan populasi dipartisi berdasarkan tingkat pendidikannya, maka nilai $I_{B}$ untuk partisi populasi ini menunjukkan besar ketimpangan yang terjadi antar penduduk dengan tingkat pendidikan yang berbeda sedangkan nilai $I_{W}$ menunjukkan besar ketimpangan yang terjadi pada penduduk dengan tingkat pendidikan yang sama.

Cowell dan Jenkins (1995) memperkenalkan suatu notasi, yaitu $R_{B}$, untuk lebih memahami interpretasi dari persamaan (2). $R_{B}=\frac{I_{B}}{I}$ adalah besarnya bagian dari ketimpangan yang dapat dijelaskan oleh suatu karakteristik. Nilai $R_{B}$ juga dapat diinterpretasikan sebagai bagian dari total ketimpangan yang dapat dijelaskan oleh partisi tersebut (Ferreira, Leite dan Litchfield, 2007). Berdasarkan analisis yang mereka lakukan, nilai $R_{B}$ yang tinggi dari suatu partisi menunjukkan bahwa karakteristik partisi tersebut adalah determinan penting untuk ketimpangan. Walaupun dekomposisi statis tidak dapat menjelaskan kausalitas, tetapi nilai $R_{B}$ yang tinggi menunjukkan terjadi ketimpangan yang tinggi antar subgrup populasi berdasarkan karakteristik partisi tersebut.

Secara matematis persamaan dekomposisi statis untuk nilai MLD $\left(I_{0}\right)$ untuk populasi yang dibagi menjadi $m$ subgrup adalah sebagai berikut $I_{0}=\sum_{k=1}^{m} \frac{n_{k}}{n} I_{0}^{k}+\sum_{k=1}^{m} \frac{\mathrm{n}_{\mathrm{k}}}{n} \log \frac{\mu}{\mu_{k}}$

dengan $n_{k}$ adalah jumlah populasi di subgrup $k, \mu_{k}$ adalah pendapatan rata-rata subgrup $k$.

Komponen pertama, $\sum_{k=1}^{m} \frac{n_{k}}{n} I_{0}^{k}$, adalah besarnya ketimpangan di dalam grup atau $I_{W}$. Nilai ini adalah rata-rata tertimbang dari ketimpangan yang terjadi pada masing-masing subgrup dengan bobot untuk masing-masing subgrup adalah proporsi populasi subgrup tersebut. Sehingga subgrup yang memiliki tingkat ketimpangan serta populasi yang relatif tinggi akan memberikan kontribusi yang besar untuk komponen ini. Semakin tinggi nilai dari $I_{W}$ mengindikasikan semakin tinggi ketimpangan yang terjadi di dalam masing-masing subgrup.

Komponen kedua, $\sum_{k=1}^{m} \frac{\mathrm{n}_{\mathrm{k}}}{n} \log \frac{\mu}{\mu_{k}}$, adalah besarnya ketimpangan antar grup atau $I_{B}$. Komponen ini adalah rata-rata tertimbang dari deviasi antara pendapatan rata-rata masing-masing subgrup terhadap pendapatan rata-rata populasi dengan 
bobot untuk masing-masing subgrup adalah proporsi populasi subgrup tersebut. Sehingga subgrup yang memiliki populasi yang relatif tinggi tetapi pendapatan rata-rata yang rendah akan memberikan kontribusi yang besar untuk komponen ini. Namun subgrup dengan pendapatan di atas rata-rata akan memberikan kontribusi negatif pada komponen ini. Semakin tinggi nilai dari $I_{B}$ mengindikasikan semakin banyaknya kelompok populasi yang memiliki pendapatan lebih rendah dari pada rata-rata. Jauhnya deviasi antara pendapatan rata-rata dengan pendapatan subgrup-subgrup tersebut menunjukkan semakin divergennya pendapatan rata-rata antar subgrup populasi.

\section{Dekomposisi Dinamis}

Dari konsep dekomposisi statis diketahui bahwa nilai pengukuran ketimpangan dapat didekomposisi menjadi nilai ketimpangan di dalam grup dan ketimpangan antar grup. Dengan demikian perubahan ketimpangan dapat didekomposisi menjadi perubahan ketimpangan di dalam grup dan perubahan ketimpangan antar grup. Perubahan ketimpangan menurut Mookherjee dan Shorrocks (1982) dapat didekomposisi menjadi berikut ini

$$
\Delta I_{0} \cong \sum_{k=1}^{m} \overline{v_{k}} \Delta I_{0}^{k}+\sum_{k=1}^{m} \overline{I_{0}^{k}} \Delta v_{k}+\sum_{k=1}^{m}\left(\overline{\lambda_{k}}-\overline{\log \lambda_{k}}\right) \Delta v_{k}+\sum_{k=1}^{m}\left(\overline{\theta_{k}}-\right.
$$

dengan $v_{k}=\frac{\mathrm{n}_{\mathrm{k}}}{n}$ adalah proporsi populasi subgrup $k$ terhadap proporsi total, $\lambda_{k}=$ $\frac{\mu_{k}}{\mu}$ adalah rasio pendapatan rata-rata populasi subgrup $k$ terhadap pendapatan ratarata populasi secara keseluruhan dan $\theta_{k}=v_{k} \lambda_{k} \cdot \overline{v_{k}}=\frac{1}{2}\left[v_{k}(t)+v_{k}(t+1)\right]$, dan $\overline{I_{0}^{k}}$ serta $\overline{\log \lambda_{k}}$ diperoleh dengan metode serupa. Nilai positif yang diperoleh pada perhitungan menujukkan bahwa komponen tersebut menyebabkan semakin divergennya distribusi pendapatan (meningkatkan ketimpangan), sedangkan nilai negatif menunjukkan komponen tersebut menyebabkan semakin konvergennya distribusi pendapatan (menurunkan ketimpangan).

Komponen pertama dari persamaan (4), menunjukkan besar perubahan ketimpangan di dalam grup terhadap perubahan ketimpangan secara keseluruhan (pure inequality effect atau unexplained effect). Komponen ini menunjukkan besarnya perubahan ketimpangan yang tidak dapat dijelaskan oleh partisi populasi tersebut (Ferreira, Leitte, dan Litchfield, 2007). Semakin besar nilai komponen ini menunjukkan semakin meningkatnya ketimpangan yang terjadi di dalam masingmasing subgrup.

Komponen kedua dan ketiga merupakan allocation effect atau efek perubahan populasi. Komponen kedua menunjukkan efek perubahan proporsi populasi yang diuraikan dari within group component (allocation effect on within group) sedangkan komponen ketiga menunjukkan efek perubahan populasi dari between group component (allocation effect on between group). Peningkatan proporsi populasi akan berkontribusi positif pada komponen ini (meningkatkan ketimpangan) karena nilai $\overline{I_{0}^{k}}$ maupun $\left(\overline{\lambda_{k}}-\overline{\log \lambda_{k}}\right)$ akan selalu bernilai positif. Besarnya kontribusi perubahan proporsi populasi suatu subgrup pada komponen ini selain berdasarkan besar perubahan proporsi populasi juga bergantung pada rata-rata nilai ketimpangan pada subgrup tersebut serta rasio pendapatan rata-rata subgrup terhadap pendapatan rata-rata populasi. Apabila subgrup tesebut memiliki ketimpangan tinggi serta pendapatan yang jauh lebih tinggi atau jauh lebih rendah dari pada pendapatan rata-rata populasi maka perubahan populasi yang terjadi 
akan memberikan kontribusi besar pada allocation effect.

Komponen terakhir adalah income effect. Komponen ini mengukur dampak perubahan pendapatan rata-rata antar grup (income effect). Koefisien $\overline{\theta_{k}}-\overline{v_{k}}$ akan bernilai positif apabila subgrup tersebut memiliki pendapatan di atas rata-rata dan negatif apabila sebaliknya. Apabila kelompok kaya mengalami peningkatan pendapatan rata-rata, maka akan berkontribusi positif pada komponen ini tetapi apabila kelompok miskin, yang memiliki pendapatan di bawah rata-rata, mengalami peningkatan pendapatan rata-rata maka akan berkontribusi negatif. Apabila kelompok miskin mengalami penurunan pendapatan, maka akan berkontribusi positif.

Ferreira, Leite dan Litchfield (2007) menyatakan apabila nilai dari pure inequality effect berdasarkan suatu karakteristik melebihi nilai keseluruhan perubahan ketimpangan yang terjadi maka perubahan proporsi populasi maupun perubahan pendapatan subgrup-subgrup pada karakteristik tersebut tidak dapat dianggap sebagai faktor yang substansial untuk menjelaskan perubahan ketimpangan yang terjadi. Hal ini dikarenakan perubahan yang berasal dari dalam masing-masing subgrup tersebut lebih dominan.

\section{Rancangan Penelitian}

Berdasarkan latar belakang dan penelitian terdahulu, pada penelitian ini populasi akan dibagi berdasarkan karakteristik rumah tangga yaitu tingkat pendidikan, lokasi rumah tangga berdasarkan kota-desa, lokasi rumah tangga berdasarkan provinsi dan status pekerjaan kepala rumah tangga. Untuk setiap karakteristik populasi akan dilakukan dekomposisi statis dan dinamis. Pada dekomposisi statis, nilai ketimpangan yang akan didikomposisi adalah ketimpangan tahun 2005, 2011, dan 2014. Untuk dekomposisi dinamis, periode 2005-2014 akan dibagi menjadi 2005-2011 dan 2011-2014, karena pada periode tersebut terjadi perubahan trend ketimpangan. Berdasarkan publikasi BPS, pada tahun 2005-2011 terjadi peningkatan koefisien Gini dari 0,363 menjadi 0,41 sedangkan pada tahun 2011-2014 nilai koefisien Gini tidak mengalami perubahan.

\section{Jenis dan Sumber Data}

Data yang digunakan pada penelitian ini adalah data pengeluaran rumah tangga tahun 2005, 2011 dan 2014 yang diperoleh dari Survey Sosial Ekonomi Nasional (Susenas) yang dilakukan oleh Badan Pusat Statistik (BPS). Variable survey yang digunakan ada pengeluaran rumah tangga, jumlah anggota rumah tangga, tingkat pendidikan kepala rumah tangga, lokasi rumah tangga, serta status pekerjaan kepala rumah tangga. Metode dekomposisi statis dan dinamis yang akan digunakan adalah dekomposisi dari indeks Theil's L atau Mean Logaritmic Deviation (MLD). Dikarenakan pada data Susenas tahun 2005 tidak ada data untuk Provinsi Aceh, Provinsi Sulawesi Barat dan Provinsi Papua Barat maka dekomposisi dinamis untuk periode 2005-2011 dilakukan tanpa memasukkan data provinsi-provinsi tersebut. Hal ini dilakukan agar hasil perhitungan pada periodeperiode ini dapat dikomparasi. Data yang digunakan adalah data-data yang mencakup semua variabel penelitian dengan demikian terdapat 257.906 data rumah tangga untuk tahun 2005, 221.799 untuk tahun 2011 dan 223,229 di tahun 2014.

\section{Definisi Variabel} penelitian ini.

Berikut penjelasan terkait variabel-variabel yang digunakan pada 


\section{1) Pendapatan per Kapita}

Nilai pendapatan diperoleh dari pengeluaran rumah tangga dalam satu bulan untuk konsumsi makanan dan non makanan. Nilai pendapatan perkapita diperoleh dari membagi pengeluaran rumah tangga dengan jumlah anggota rumah tangga. Bobot yang digunakan untuk masing-masing nilai tersebut adalah nilai variabel weind yang diberikan pada data Susenas.

2) Pendidikan

Pendidikan yang dimaksud adalah ijazah tertinggi yang dimiliki kepala rumah tangga. Berdasarkan variable ini, populasi akan dibagi menjadi sembilan subgrup yaitu : tidak berijazah, SD, SMP,SMA, SMK, D1/D2, D3, S1, S2/S3.

3) Kota-Desa

Berdasarkan lokasi kota-desa rumah tangga, populasi akan dibagi menjadi dua subgrup: Kota dan Desa.

4) Provinsi

Berdasarkan lokasi provinsi rumah tangga, populasi akan dibagi menjadi 30 subgrup sesuai jumlah provinsi yang ada pada data Susenas 2005 .

5) Status Pekerjaan

Terdapat enam kategori status pekerjaan pada data susenas yaitu Berusaha Sendiri, Berusaha Dibantu Buruh Tidak Tetap/Buruh Tidak Dibayar, Pekerja Bebas, Pekerja Keluarga Atau Tidak Dibayar, Buruh/Karyawan/Pegawai, Berusaha Dibantu Buruh Tetap/Buruh Dibayar. Empat status pertama dikategorikan sebagai pekerja informal dan dua status terakhir adalah pekerja formal. Agar dapat lebih mengamati perubahan komposisi dan pendapatan yang terjadi, maka berdasarkan status pekerjaan, populasi dibagi menjadi enam subgrup ini.

\section{HASIL DAN PEMBAHASAN Deskripsi Statistik}

Bagian ini menunjukkan ringkasan statistik terkait distribusi pendapatan. Pengukuran ketimpangan yang ditampilkan adalah koefisien Gini dari publikasi BPS dan nilai MLD dari perhitungan berdasarkan data Susenas.

Tabel 1. Tingkat Pendapatan dan Pengukuran Ketimpangan di Indonesia tahun 2005, 2011 dan 2014

\begin{tabular}{|ccccc|}
\hline Tahun & Pendapatan Rata-rata & Median Pendapatan & Gini & $\boldsymbol{I}_{\mathbf{0}}$ \\
\hline 2005 & $\operatorname{Rp~218,523}$ & $\mathrm{Rp} \mathrm{160,365}$ & 0.363 & 0.2319 \\
2011 & $\mathrm{Rp} \mathrm{565,853}$ & $\mathrm{Rp} \mathrm{410,712}$ & 0.41 & 0.2494 \\
2014 & $\mathrm{Rp} \mathrm{718,919}$ & $\mathrm{Rp} \mathrm{511,731}$ & 0.41 & 0.2575 \\
\hline
\end{tabular}

Catatan : pendapatan adalah rata-rata konsumsi perkapita setiap bulan

Sumber : Perhitungan penulis dari data SUSENAS 2005, 2011 dan 2014 dan publikasi BPS untuk Gini.

Pada setiap tahun observasi, nilai pendapatan rata-rata dan median pendapatan meningkat setiap tahunnya, namun peningkatan pendapatan rata-rata selalu lebih tinggi dari pada peningkatan median. Dari tahun 2005 hingga 2011, pendapatan rata-rata meningkat 1,58 kali sedangkan median pendapatan meningkat 1,56 kali. Dari tahun 2011 hingga 2014 pendapatan rata-rata meningkat $27,05 \%$ dan median pendapatan meningkat 24,60\%. Pengukuran MLD juga menunjukkan pola yang sama. Dari tahun 2005 hingga 2011, nilai MLD meningkat 7,55\% dan dari tahun 2011 hingga 2014 meningkat 3,25\% walaupun 
pada periode tersebut publikasi nilai koefisien Gini dari BPS menunjukkan nilai yang sama.

Selain itu median pendapatan selalu bernilai lebih rendah dari pada pendapatan rata-rata dan deviasi antara pendapatan rata-rata dan median semakin melebar setiap tahunnya. Pada tahun 2005, median pendapatan $25,70 \%$ lebih rendah dari pada pendapatan rata-rata. Pada tahun 2011, selisih antara median dan pendapatan rata-rata meningkat menjadi $27,41 \%$ dan $28,88 \%$ di tahun 2014 . Hal ini berarti pada tahun-tahun tersebut, lebih dari $50 \%$ populasi memiliki pendapatan lebih rendah dari pendapatan rata-rata populasi. Selain itu, pertumbuhan pendapatan populasi yang memiliki pendapatan lebih tinggi dari pendapatan rata-rata, lebih tinggi dari pada pertumbuhan pendapatan populasi dengan pendapatan lebih rendah dari pada pendapatan rata-rata. Dari Gambar 1 juga terlihat bahwa gap pendapatan tiap tahunnya lebih lebar pada persentil populasi dengan tingkat pendapatan yang lebih tinggi dari pada rata-rata.

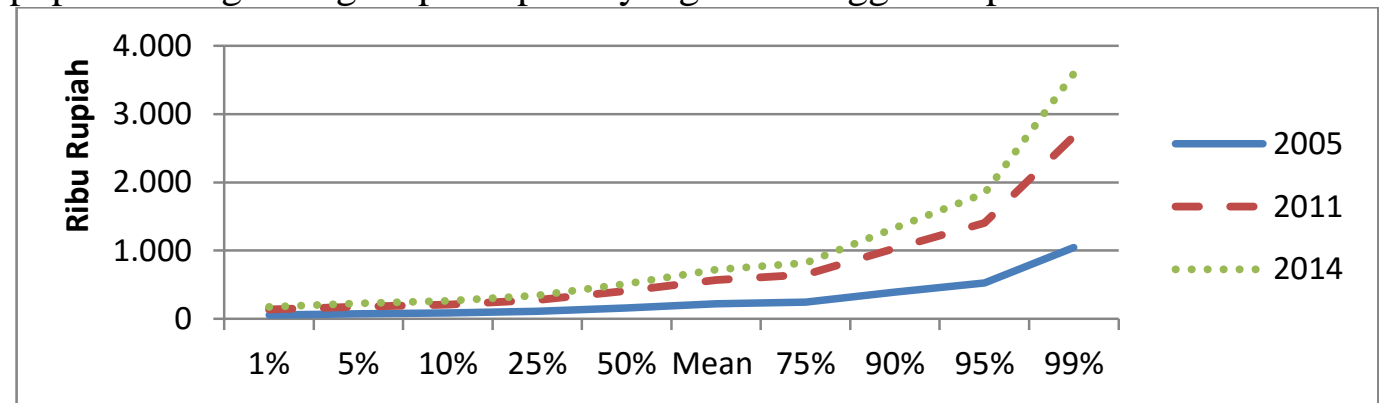

Sumber : Perhitungan penulis dari data SUSENAS 2005, 2011 dan 2014.

\section{Dekomposisi Statis}

Gambar 1. Pendapatan Rata-rata berdasarkan Persentil

Hasil dari dekomposisi statis untuk between group component dapat dilihat pada Tabel 3. Nilai-nilai yang ditunjukkan pada Tabel 2 adalah persentase dari $R_{B}$, yaitu bagian dari total ketimpangan yang dapat dijelaskan oleh masingmasing partisi.

Tabel 2. Persentase Total Ketimpangan yang Dijelaskan Perbedaan antar Grup

\begin{tabular}{|lccc|}
\hline Partisi & $\mathbf{2 0 0 5}$ & $\mathbf{2 0 1 1}$ & $\mathbf{2 0 1 4}$ \\
\hline Pendidikan & $30,60 \%$ & $26,95 \%$ & $26,30 \%$ \\
Kota-Desa & $21,97 \%$ & $12,44 \%$ & $12,49 \%$ \\
Provinsi & $18,21 \%$ & $11,83 \%$ & $11,30 \%$ \\
Status Pekerjaan & $12,26 \%$ & $15,15 \%$ & $14,25 \%$ \\
\hline
\end{tabular}

Sumber: Perhitungan penulis dari data SUSENAS 2005, 2011 dan 2014.

Hasil dari dekomposisi statis menunjukkan nilai $R_{B}$ tertinggi adalah partisi pendidikan. Nilai $R_{B}$ dari partisi ini berikisar antara $26,30 \%$ sampai $30,60 \%$ bergantung pada tahunnya. Nilai $R_{B}$ pada partisi pendidikan ini hampir dua kali lebih tinggi dari pada partisi berdasarkan karakteristik lainnya. Studi serupa yang dilakukan oleh Ferreira, Leite dan Litchfield (2007) di Brazil untuk beberapa karakteristik juga menunjukkan bahwa partisi pendidikan memiliki nilai $R_{B}$ tertinggi, bahkan 3 kali lipat lebih tinggi dari partisi-partisi lainnya. Penelitian yang mereka lakukan menghasilkan kesimpulan bahwa pendidikan merupakan determinan paling penting terhadap terjadinya ketimpangan karena besarnya ketimpangan yang dapat dijelaskan oleh karakteristik tersebut lebih tinggi dari pada karakteristik lainnya. Pada penelitian ini ketimpangan yang dapat dijelaskan oleh karakteristik pendidikan juga lebih tinggi dari pada karakteristik lainnya. Tingginya nilai $R_{B}$ pada partisi pendidikan menunjukkan bahwa lebih dari $25 \%$ 
dari ketimpangan yang terjadi dapat dijelaskan oleh perbedaan tingkat pendidikan kepala rumah tangga. Dengan demikian pada penelitian kali ini perbedaan tingkat pendidikan juga merupakan determinan utama terjadinya ketimpangan.

Partisi kota-desa dan provinsi juga mennunjukkan nilai $R_{B}$ yang cukup tinggi. Partisi kota-desa dapat menjelaskan antara 12,44\% hingga $21,97 \%$ dari total ketimpangan sedangkan partisi provinsi dapat menjelaskan antara $11,30 \%$ hingga $18,21 \%$ dari total ketimpangan. Partisi berdasarkan status pekerjaan juga menunjukkan $R_{B}$ yang cukup tinggi, bahkan melebihi partisi kota-desa dan partisi provinsi di tahun 2011 dan 2014. Hal ini menunjukkan ketimpangan yang terjadi antara populasi dengan perbedaan status pekerjaan kepala rumah tangga ini lebih tinggi dari pada ketimpangan yang terjadi antara populasi berdasarkan lokasinya. Nilai $R_{B}$ dari partisi pendidikan, kota-desa maupun partisi provinsi ketiganya menunjukkan pola yang sama yaitu menurun setiap tahunnya, sedangkan partisi berdasarkan status pekerjaan menunjukkan trend peningkatan pada tahun 20112014 dan menurun pada 2011-2014. Trend ini akan dibahas lebih lanjut pada dekomposisi dinamis.

\section{Dekomposisi Dinamis tahun 2005-2011}

Hasil dekomposisi dinamis untuk tahun 2005-2011 akan ditampilkan pada Tabel 3.

Tabel 3. Dekomposisi Dinamis Periode 2005-2011

\begin{tabular}{|lcccc|}
\hline \multicolumn{4}{c}{ Proporsi perubahan $I_{0}=0,0755$} \\
\hline \multicolumn{1}{c}{ Partisi } & $\begin{array}{c}\text { Pure Inequality } \\
\text { Effect }\end{array}$ & $\begin{array}{c}\text { Allocation Effect } \\
\text { on Within Group }\end{array}$ & $\begin{array}{c}\text { Allocation Effect } \\
\text { on Between } \\
\text { Group }\end{array}$ & Income Effect \\
\hline Pendidikan & 0,0578 & 0,0269 & 0,0483 & $-0,0553$ \\
Kota-Desa & 0,1368 & 0,0266 & $-0,0009$ & $-0,0866$ \\
Provinsi & 0,1331 & 0,0028 & $-0,0002$ & $-0,0547$ \\
Status Pekerjaan & 0.0088 & 0.0265 & 0.0017 & 0.0297 \\
\hline
\end{tabular}

Sumber : Perhitungan penulis dari data SUSENAS 2005 dan 2011

Dari tahun 2005 hingga 2011, nilai pure inequality effect pada partisi kotadesa dan provinsi menunjukkan nilai yang lebih besar dari pada proporsi perubahan $I_{0}$ hal ini berarti perubahan pendapatan rata-rata dan perubahan proporsi populasi pada partisi kota-desa dan provinsi tidak dapat menjelaskan peningkatan ketimpangan yang terjadi pada periode ini. Namun terjadi konvergensi pendapatan antara populasi di desa dengan kota, hal ini menjadi indikasi bahwa upaya pemerintah untuk meningkatkan pendapatan di desa telah berhasil menurunkan ketimpangan antara kota dengan desa. Hal ini ditunjukkan oleh komponen income iffect yang negatif, namun kondisi ini berlawanan dengan trend perubahan ketimpangan yang terjadi. Perubahan keimpangan yang terjadi di dalam grup melebihi pengaruh dari income effect tersebut.

Jika dilihat lebih detil dari hasil dekomposisi dinamis untuk partisi kotadesa pada periode 2005-2011 di Tabel 4, kontributor terbesar untuk komponen pure inequality effect adalah subgrup desa. Tingginya kontribusi subgrup desa untuk komponen ini diduga akibat kenaikan harga bahan bakar minyak (BBM) yang terjadi pada periode 2005-2011. Pada periode tersebut, terjadi kenaikan harga BBM yang cukup tinggi pada tahun 2005 yaitu dari Rp 2.400,00 menjadi Rp 4.500,00 dan pada tahun 2008 naik menjadi Rp 6.000,00. Peningkatan harga BBM pada periode ini menurut Utari dan S. Retni (2014) mengakibatkan 
terjadinya inflasi yang akan berdampak lebih buruk pada masyarakat berpenghasilan rendah. Berdasarkan data BPS, pada periode tersebut $60 \%$ penduduk miskin tinggal di desa. Dengan demikian pengaruh kenaikan harga BBM pada periode ini akan lebih berdampak di desa.

Tabel 4. Dekomposisi Dinamis Partisi Kota-Desa Tahun 2005-2011

\begin{tabular}{|lrrrr|}
\hline \multicolumn{5}{c|}{ Proporsi perubahan $I_{0}=0,0755$} \\
\hline Subgrup & $\begin{array}{c}\text { Pure Inequality } \\
\text { Effect }\end{array}$ & $\begin{array}{c}\text { Allocation Effect } \\
\text { on Within Group }\end{array}$ & $\begin{array}{c}\text { Allocation Effect } \\
\text { on Between } \\
\text { Group }\end{array}$ & Income Effect \\
\hline Kota & 0.0374 & 0.0668 & 0.2735 & 0.5204 \\
Desa & 0.0994 & -0.0402 & -0.2744 & -0.6070 \\
Total & $\mathbf{0 . 1 3 6 8}$ & $\mathbf{0 . 0 2 6 6}$ & $\mathbf{- 0 . 0 0 0 9}$ & $\mathbf{- 0 . 0 8 6 6}$ \\
\hline
\end{tabular}

Sumber : Perhitungan penulis dari data SUSENAS 2005 dan 2011

Hasil dekomposisi dinamis untuk partisi provinsi juga menunjukkan nilai pure inequality effect yang lebih besar dari pada proporsi perubahan $I_{0}$. Dilihat lebih detil di Tabel 5, kontributor terbesar untuk komponen ini adalah Provinsi Jawa Barat dan Jawa Tengah. Kedua provinsi ini, berdasarkan data BPS, merupakan provinsi dengan jumlah penduduk miskin yang tinggi. Pada tahun 2007, lebih dari 15\% penduduk miskin berada di Provinsi Jawa Barat dan Jawa Tengah. Maka dari itu, tingginya kontribusi kedua provinsi ini untuk komponen pure inequality effect kemungkinan juga disebabkan oleh kenaikan harga BBM pada periode 2005-2011. Namun Provinsi Jawa Timur, yang merupakan provinsi dengan persentase penduduk miskin tertinggi, malah mengalami penurunan ketimpangan. Jika dilihat berdasarkan partisi provinsi ini, diduga kenaikan harga BBM bukan lah satu-satunya faktor yang memicu peningkatan ketimpangan pada periode 2005-2011.

Tabel 5 Dekomposisi Dinamis Partisi Provinsi Tahun 2005-2011

\begin{tabular}{|c|c|c|c|c|}
\hline \multicolumn{5}{|c|}{ Proporsi perubahan $I_{0}=0,0755$} \\
\hline Subgrup & $\begin{array}{c}\text { Pure } \\
\text { Inequality } \\
\text { Effect }\end{array}$ & $\begin{array}{l}\text { Allocation Effect } \\
\text { on Within Group }\end{array}$ & $\begin{array}{c}\text { Allocation Effect } \\
\text { on Between } \\
\text { Group }\end{array}$ & Income Effect \\
\hline Sumatera Utara & -0.0033 & 0.0033 & 0.0197 & -0.0088 \\
\hline Sumatera Barat & 0.0010 & 0.0006 & 0.0035 & 0.0007 \\
\hline Riau & 0.0008 & 0.0032 & 0.0176 & 0.0220 \\
\hline Jambi & 0.0013 & 0.0015 & 0.0085 & -0.0001 \\
\hline Sumatera Selatan & 0.0095 & 0.0018 & 0.0101 & -0.0199 \\
\hline Bengkulu & 0.0023 & 0.0004 & 0.0022 & -0.0045 \\
\hline Lampung & -0.0003 & 0.0018 & 0.0094 & -0.0263 \\
\hline Kep. Bangka & & & & \\
\hline Belitung & -0.0001 & 0.0009 & 0.0065 & 0.0078 \\
\hline Kepulauan Riau & -0.0002 & 0.0022 & 0.0118 & 0.0174 \\
\hline DKI Jakarta & -0.0007 & -0.0022 & -0.0117 & 0.1766 \\
\hline Jawa Barat & 0.0475 & -0.0059 & -0.0272 & 0.0112 \\
\hline Jawa Tengah & 0.0365 & -0.0038 & -0.0221 & -0.1259 \\
\hline DI Yogyakarta & -0.0011 & -0.0002 & -0.0007 & 0.0073 \\
\hline Jawa Timur & -0.0002 & -0.0065 & -0.0325 & -0.1000 \\
\hline Banten & -0.0020 & 0.0012 & 0.0044 & 0.0461 \\
\hline Bali & 0.0046 & 0.0021 & 0.0105 & 0.0206 \\
\hline NTB & 0.0034 & -0.0031 & -0.0174 & -0.0195 \\
\hline NTT & -0.0001 & 0.0017 & 0.0102 & -0.0364 \\
\hline Kalimantan Barat & 0.0048 & -0.0014 & -0.0075 & -0.0078 \\
\hline Kalimantan Tengah & 0.0020 & 0.0000 & 0.0000 & 0.0002 \\
\hline Kalimantan Selatan & 0.0027 & -0.0004 & -0.0019 & 0.0101 \\
\hline
\end{tabular}




\begin{tabular}{|lrrrr|}
\hline \multicolumn{5}{|c|}{ Proporsi perubahan $I_{0}=0,0755$} \\
\hline Subgrup & $\begin{array}{c}\text { Pure } \\
\text { Inequality } \\
\text { Effect }\end{array}$ & $\begin{array}{c}\text { Allocation Effect } \\
\text { on Within Group }\end{array}$ & $\begin{array}{c}\text { Allocation Effect } \\
\text { on Between } \\
\text { Group }\end{array}$ & Income Effect \\
\hline Kalimantan Timur & -0.0011 & 0.0027 & 0.0146 & 0.0302 \\
Sulawesi Utara & 0.0022 & 0.0000 & 0.0000 & 0.0014 \\
Sulawesi Tengah & 0.0021 & 0.0010 & 0.0054 & -0.0082 \\
Sulawesi Selatan & 0.0161 & -0.0073 & -0.0317 & -0.0307 \\
Sulawesi Tenggara & 0.0036 & 0.0001 & 0.0006 & -0.0095 \\
Gorontalo & 0.0014 & 0.0006 & 0.0023 & -0.0040 \\
Maluku & 0.0021 & 0.0012 & 0.0068 & -0.0048 \\
Maluku Utara & -0.0004 & 0.0013 & 0.0070 & -0.0019 \\
Papua & -0.0012 & 0.0004 & 0.0016 & 0.0021 \\
Total & $\mathbf{0 . 1 3 3 1}$ & $\mathbf{- 0 . 0 0 2 8}$ & $\mathbf{- 0 . 0 0 0 2}$ & $\mathbf{- 0 . 0 5 4 7}$ \\
\hline
\end{tabular}

Sumber : Perhitungan penulis dari data SUSENAS 2005 dan 2011

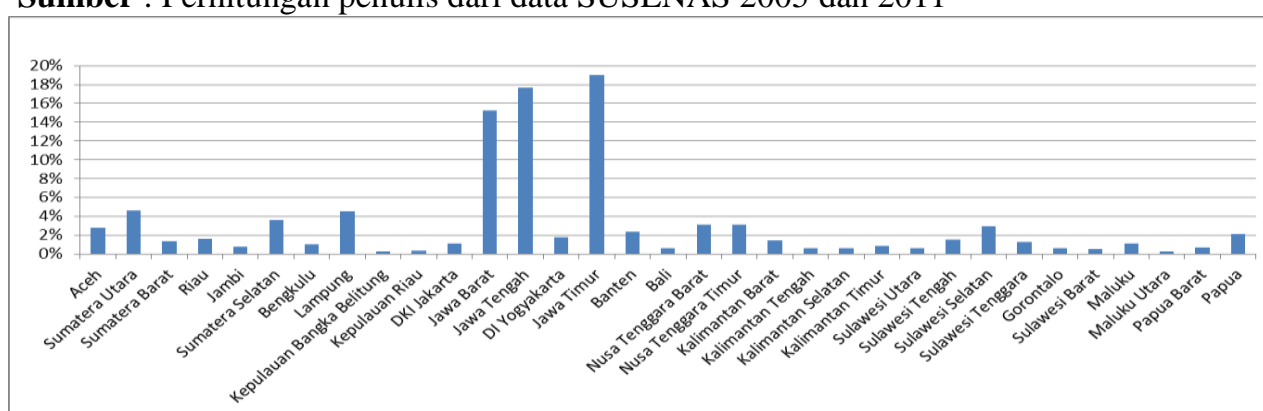

Sumber : Data BPS

Gambar 2 Sebaran Penduduk Miskin berdasarkan Provinsi di Indonesia tahun 2007

Di sisi lain, untuk partisi pendidikan, nilai pure inequality effect pada partisi ini menunjukkan nilai yang lebih rendah dari pada proporsi perubahan $I_{0}$. Dari 7,55\% perubahan ketimpangan yang terjadi, 7,52\% dapat dijelaskan oleh allocation effect. Namun juga terdapat income effect yang bersifat mengurangi ketimpangan yang terjadi antara penduduk dengan tingkat pendidikan kepala rumah tangga yang berbeda. Dilihat lebih detil pada Tabel 6 pada periode ini terjadi efek perubahan proporsi populasi yang besifat mengurangi ketimpangan yang berasal dari subgrup penduduk dengan kepala rumah tangga yang tidak memiliki ijazah pendidikan dan memiliki ijazah SD/MI. Hal ini dikarenakan terjadi penurunan proporsi populasi pada kedua subgrup tersebut. Walaupun terjadi pengurangan ketimpangan, di sisi lain proporsi populasi penduduk dengan tingkat pendidikan kepala rumah tangga SMP/MTS, SMA/MA, SMK dan S1 mengalami peningkatan yang secara total lebih berefek meningkatkan ketimpangan. Hal ini menunjukkan, penurunan proporsi populasi dengan pendidikan kepala rumah tangga rendah tersebut tidak cukup berkontribusi pada komponen allocation effect.

Tabel 6. Dekomposisi Dinamis Partisi Pendidikan Tahun 2005-2011

\begin{tabular}{|lrrrr|}
\hline \multicolumn{5}{|c|}{ Proporsi perubahan $I_{0}=0,0755$} \\
\hline Subgrup & $\begin{array}{c}\text { Pure Inequality } \\
\text { Effect }\end{array}$ & $\begin{array}{c}\text { Allocation Effect } \\
\text { on Within Group }\end{array}$ & $\begin{array}{c}\text { Allocation Effect } \\
\text { on Between } \\
\text { Group }\end{array}$ & Income Effect \\
\hline Tidak Berijazah & & & & -0.2920 \\
SD & 0.0303 & -0.0523 & -0.3860 & -0.3070 \\
SMP & 0.0283 & -0.0001 & -0.0008 & -0.0322 \\
SMA & 0.0119 & 0.0153 & 0.0901 & 0.1900
\end{tabular}




\begin{tabular}{|lrrrr|}
\hline \multicolumn{5}{c|}{ Proporsi perubahan $I_{0}=0,0755$} \\
\hline Subgrup & $\begin{array}{c}\text { Pure Inequality } \\
\text { Effect }\end{array}$ & $\begin{array}{c}\text { Allocation Effect } \\
\text { on Within Group }\end{array}$ & $\begin{array}{c}\text { Allocation Effect } \\
\text { on Between } \\
\text { Group }\end{array}$ & Income Effect \\
\hline SMK & & & 0.0692 & 0.0568 \\
D1/D2 & 0.0009 & 0.0121 & -0.0151 & 0.0166 \\
D3 & 0.0013 & -0.0028 & 0.0082 & 0.0638 \\
D4/s1 & 0.0018 & 0.0016 & 0.1220 & 0.2124 \\
S2/S3 & -0.0086 & 0.0227 & 0.0333 & 0.0364 \\
Total & -0.0030 & 0.0043 & $\mathbf{0 . 0 5 5 3}$ \\
\hline
\end{tabular}

Sumber : Perhitungan penulis dari data SUSENAS 2005 dan 2011

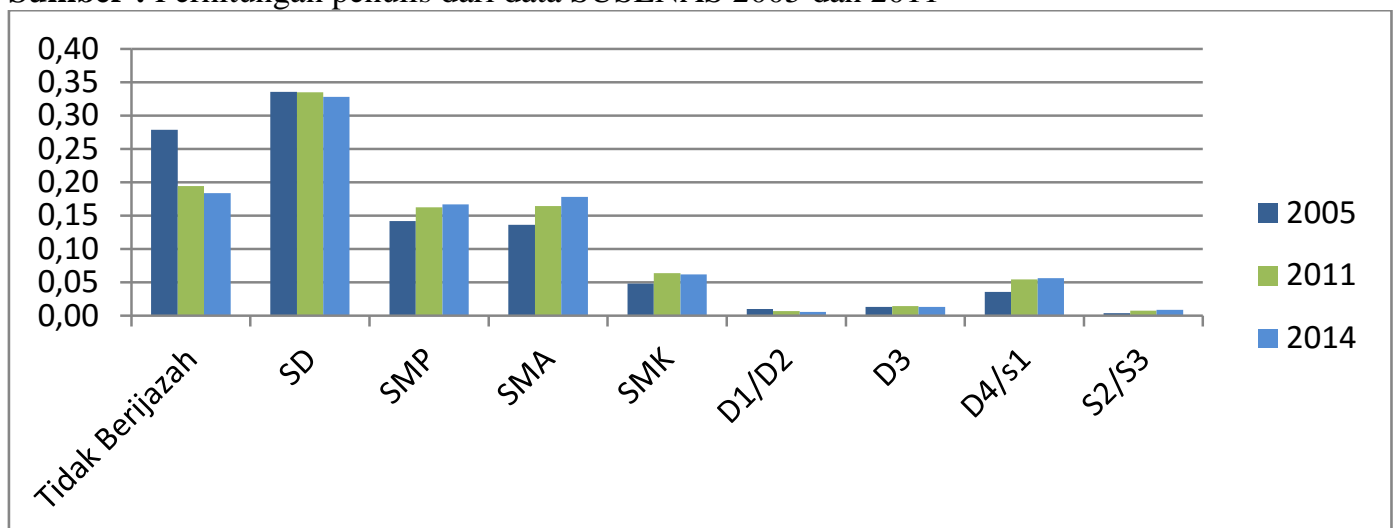

Sumber : Perhitungan penulis dari data SUSENAS 2005, 2011 dan 2014.

Gambar 3. Proporsi Populasi Indonesia berdasarkan Pendidikan Tertinggi Kepala

Rumah Tangga tahun 2005, 2011 dan 2014

Komponen income effect pada periode ini bernilai negatif. Ini mengindikasikan kebijakan-kebijakan pemerintah pada periode ini telah berhasil meningkatkan pendapatan masyarakat berpendidikan rendah. Peningkatan pendapatan rata-rata populasi dengan kepala rumah tangga yang tidak memiliki ijazah pendidikan, memiliki ijazah SD/MI, dan memiliki ijazah SMP/MTS memberikan kontribusi yang lebih besar pada komponen income effect dari pada peningkatan pendapatan rata-rata populasi dengan tingkat pendidikan kepala rumah tangga SMA/MA ke atas. Hal ini membuat terjadinya konvergensi antar pendapatan rata-rata populasi dengan pendidikan kepala rumah tangga yang berbeda ini. Namun secara keseluruhan nilai komponen allocation effect lebih besar dari pada income effect, sehingga perubahan proporsi populasi lah yang lebih dapat menjelaskan peningkatan ketimpangan yang terjadi.

Partisi status pekerjaan juga menunjukkan nilai pure inequality effect yang lebih rendah dari pada proporsi perubahan $I_{0}$. Dari 7,55\% perubahan ketimpangan yang terjadi, 2,82\% dapat dijelaskan oleh allocation effect dan 2,97\% dapat dijelaskan oleh income effect. Pada periode ini sector-sektor formal berkebang jauh lebih tinggi dari pada sektor informal. Hal ini ditunjukkan oleh peningkatan proporsi populasi pada subgrup-subgrup pekerja formal yang memberikan kontribusi besar pada komponen allocation effect, di sisi lain proporsi populasi dari subgrup-subgrup informal mengalami penurunan. Income effect pada periode ini juga bernilai positif. Hal ini terutama berasal dari peningkatan pendapatan subgrup-subgrup pekerja formal. Walaupun subgrup-subgrup pekerja informal juga mengalami peningkatan pendapatan, tetapi kontribusimya masih lebih rendah dari pada kontribusi akibat peningkatan pendapatan subgrup-subgrup 
pekerja formal.

Tabel 7. Dekomposisi Dinamis Partisi Status Pekerjaan Tahun 2005-2011

\begin{tabular}{|lcccc|}
\hline \multicolumn{4}{|c|}{ Proporsi perubahan $I_{0}=0,0755$} & \\
\hline Subgrup & $\begin{array}{c}\text { Pure } \\
\text { Inequality } \\
\text { Effect }\end{array}$ & $\begin{array}{c}\text { Allocation } \\
\text { Effect on } \\
\text { Within Group }\end{array}$ & $\begin{array}{c}\text { Allocation } \\
\text { Effect on } \\
\text { Between } \\
\text { Group }\end{array}$ & $\begin{array}{c}\text { Income } \\
\text { Effect }\end{array}$ \\
\hline Berusaha Sendiri & 0.0214 & -0.0275 & -0.1482 & -0.1022 \\
Berusaha Dibantu Buruh & 0.0515 & 0.0074 & 0.0455 & -0.2508 \\
Tidak Tetap & -0.0584 & -0.0460 & -0.2814 & -0.0816 \\
Pekerja Bebas & -0.0001 & -0.0007 & -0.0036 & -0.0033 \\
Pekerja Tidak Dibayar & 0.0048 & 0.0840 & 0.3604 & 0.3177 \\
Buruh/Karyawan/Pegawai & & & & \\
Berusaha Dibantu Buruh & -0.0104 & 0.0091 & 0.0290 & 0.1500 \\
Dibayar & $\mathbf{0 . 0 0 8 8}$ & $\mathbf{0 . 0 2 6 5}$ & $\mathbf{0 . 0 0 1 7}$ & $\mathbf{0 . 0 2 9 7}$ \\
Total & & & & \\
\hline
\end{tabular}

Sumber : Perhitungan penulis dari data SUSENAS 2005 dan 2011

\section{Dekomposisi Dinamis tahun 2011-2014}

Hasil dekomposisi dinamis untuk tahun 2011-2014 akan ditampilkan pada Tabel 8.

Tabel 8 Dekomposisi Dinamis Periode 2011-2014

\begin{tabular}{|lcccc|}
\hline \multicolumn{4}{c|}{ Proporsi perubahan $I_{0}=0,0329$} \\
\hline Partisi & $\begin{array}{c}\text { Pure Inequality } \\
\text { Effect }\end{array}$ & $\begin{array}{c}\text { Allocation Effect } \\
\text { on Within Group }\end{array}$ & $\begin{array}{c}\text { Allocation Effect } \\
\text { on Between } \\
\text { Group }\end{array}$ & Income Effect \\
\hline Pendidikan & 0.0207 & 0.0045 & 0.0051 & 0.0022 \\
Kota-Desa & 0.0274 & 0.0009 & 0 & 0.0041 \\
Provinsi & 0.0261 & 0 & 0.0005 & 0 \\
Status Pekerjaan & 0.0372 & -0.0005 & 0 & -0.0043 \\
\hline
\end{tabular}

Sumber: Perhitungan penulis dari data SUSENAS 2011 dan 2014

Pada tahun 2011-2014 terjadi peningkatan MLD sebesar 3,29\%. Pada periode ini partisi berdasarkan status pekerjaan memiliki nilai pure inequality effect lebih tinggi dari pada proporsi perubahan $I_{0}$. Hal ini berarti perubahan pendapatan rata-rata dan perubahan proporsi populasi pada partisi ini tidak dapat dianggap sebagai faktor yang substansial dalam menjelaskan peningkatan ketimpangan yang terjadi pada periode tersebut. Perubahan ketimpangan yang terjadi di dalam grup lebih dapat menjelaskan perubahan ketimpangan yang terjadi. Partisi berdasarkan kota-desa, provinsi dan terutama pendidikan memiliki nilai pure inequality effect yang lebih rendah dari proporsi perubahan $I_{0}$ sehingga perubahan populasi dan perubahan pendapatan yang terjadi pada grup-grup partisi ini dapat menjelaskan penyebab peningkatan ketimpangan. Pada partisi provinsi, walaupun nilai pure inequality effect yang lebih rendah dari proporsi perubahan $I_{0}$ tapi nilai dari komponen income effect maupun allocation effect relatif sangat kecil.

Pada partisi berdasarkan pendidikan, nilai komponen pure inequality effect lebih rendah proporsi perubahan $I_{0}$. Dari 3,29\% peningkatan indeks MLD yang terjadi $0,96 \%$ dapat dijelaskan dari allocation effect dan 0,22\% yang dijelaskan oleh income effect. Pada periode ini penurunan proporsi populasi dengan pendidikan kepala rumah tangga rendah tersebut masih tidak cukup berkontribusi pada komponen allocation effect. Dilihat dari Tabel 9, terjadi penurunan proporsi populasi berasal dari subgrup penduduk dengan kepala rumah tangga yang tidak 
memiliki ijazah pendidikan dan memiliki ijazah SD/MI. Namun, proporsi populasi penduduk dengan tingkat pendidikan kepala rumah tangga SMP/MTS, SMA/MA, dan D4/S1 mengalami peningkatan yang secara total berkontribusi lebih tinggi pada allocation effect.

Jika pada tahun 2005-2011 terjadi konvergensi upah antara penduduk dengan tingkat pendidikan yang berbeda, pada periode ini gap pendapatan penduduk dengan tingkat pendidikan kepala keluarga yang berbeda semakin meningkat. Diduga pada periode ini terjadi peningkatan return to schooling. Dilihat dari nilai komponen income effect, peningkatan pendapatan rata-rata populasi dengan kepala rumah tangga yang tidak memiliki ijazah pendidikan, memiliki ijazah SD/MI, dan memiliki ijazah SMP/MTS memberikan kontribusi yang lebih rendah pada komponen income effect dari pada peningkatan pendapatan rata-rata populasi dengan tingkat pendidikan kepala rumah tangga SMA/MA ke atas. Sehingga, peningkatan pendapatan rata-rata populasi dengan pendidikan kepala rumah tangga rendah tidak cukup berkontribusi pada komponen income effect.

Tabel 10. Dekomposisi Dinamis Partisi Pendidikan Tahun 2011-2014

\begin{tabular}{|c|c|c|c|c|}
\hline \multicolumn{5}{|c|}{ Proporsi perubahan $I_{0}=0,0329$} \\
\hline Subgrup & $\begin{array}{c}\text { Pure Inequality } \\
\text { Effect }\end{array}$ & $\begin{array}{l}\text { Allocation Effect } \\
\text { on Within Group }\end{array}$ & $\begin{array}{c}\text { Allocation Effect } \\
\text { on Between } \\
\text { Group }\end{array}$ & Income Effect \\
\hline Tidak Berijazah & -0.0049 & -0.0067 & -0.0460 & -0.0558 \\
\hline SD & 0.0054 & -0.0045 & -0.0289 & -0.0795 \\
\hline SMP & 0.0033 & 0.0031 & 0.0173 & -0.0134 \\
\hline SMA & 0.0120 & 0.0126 & 0.0586 & 0.0393 \\
\hline SMK & 0.0028 & -0.0016 & -0.0088 & 0.0127 \\
\hline $\mathrm{D} 1 / \mathrm{D} 2$ & 0.0001 & -0.0011 & -0.0053 & 0.0033 \\
\hline D3 & -0.0014 & -0.0011 & -0.0054 & 0.0128 \\
\hline $\mathrm{D} 4 / \mathrm{s} 1$ & 0.0023 & 0.0022 & 0.0121 & 0.0624 \\
\hline $\mathrm{S} 2 / \mathrm{S} 3$ & 0.0010 & 0.0014 & 0.0115 & 0.0203 \\
\hline Total & 0.0207 & 0.0045 & 0.0051 & 0.0022 \\
\hline
\end{tabular}

Sumber: Perhitungan penulis dari data SUSENAS 2011 dan 2014

Pada partisi berdasarkan kota-desa nilai komponen pure inequality effect lebih rendah proporsi perubahan $I_{0}$. Allocation effect dan income effect bernilai positif, sesuai dengan trend perubahan ketimpangan yang terjadi. Walaupun begitu allocation effect dari partisi kota-desa ini relatif sangat kecil. Pola urbanisasi yang terjadi pada periode ini bersifat meningkatkan ketimpangan karena allocation effect pada partisi kota-desa secara keseluruhan bernilai positif walaupun relative kecil. Namun besarnya nilai komponen allocation effect ini masih lebih rendah dari pada komponen income effect. Dengan kata lain untuk partisi ini peningkatan ketimpangan yang terjadi lebih dapat dijelaskan oleh perubahan pendapatan.

Pada periode ini gap antara pendapatan penduduk di kota dan desa semakin tinggi. Hal ini ditunjukkan oleh nilai income effect pada periode yang bernilai positif. Dari Tabel 11 terlihat bahwa peningkatan pendapatan populasi di perkotaan berkontribusi lebih besar dari pada peningkatan pendapatan populasi di desa. Hal ini menyebabkan semakin divergennya pendapatan antara masyarakat perkotaan dan pedesaan. Pada periode ini juga terjadi peningkatan harga BBM, namun diduga hal ini bukanlah pemicu peningkatan ketimpangan yang terjadi jika 
dilihat berdasarkan partisi kota-desa. Dilihat dari nilai komponen pure inequality effect, pada periode ini telah terjadi penurunan ketimpangan di desa. Apabila peningkatan harga BBM memicu peningkatan ketimpangan, seharusnya juga terjadi peningkatan ketimpangan di desa karena terdapat lebih banyak terdapat penduduk miskin. Di sisi lain daerah perkotaan mengalami peningkatan ketimpangan yang cukup tinggi.

Tabel 11. Dekomposisi Dinamis Partisi Kota-Desa Tahun 2011-2014

\begin{tabular}{|c|c|c|c|c|}
\hline \multicolumn{5}{|c|}{ Proporsi perubahan $I_{0}=0,0329$} \\
\hline Subgrup & $\begin{array}{c}\text { Pure Inequality } \\
\text { Effect }\end{array}$ & $\begin{array}{l}\text { Allocation Effect } \\
\text { on Within Group }\end{array}$ & $\begin{array}{c}\text { Allocation Effect } \\
\text { on Between } \\
\text { Group }\end{array}$ & Income Effect \\
\hline Kota & 0.0473 & 0.0024 & 0.0088 & 0.1188 \\
\hline Desa & -0.0199 & -0.0015 & -0.0089 & -0.1147 \\
\hline Total & 0.0274 & 0.0009 & -0.0001 & 0.0041 \\
\hline
\end{tabular}

Sumber : Perhitungan penulis dari data SUSENAS 2011 dan 2014

Pada partisi berdasarkan provinsi, nilai komponen pure inequality effect lebih rendah dari pada proporsi perubahan $I_{0}$. Walaupun begitu allocation effect dan income effect pada partisi ini relatif sangat kecil. Juga, terdapat selisih yang cukup jauh antara jumlah komponen-komponen dekomposisi dengan perubahan ketimpangan yang terjadi.

Secara keseluruhan nilai income effect adalah 0. Ini menunjukkan income effect tidak dapat menjelaskan peningkatan ketimpangan yang terjadi. Walaupun terdapat kontribusi negatif dari peningkatan pendapatan populasi terutama di Provinsi Jawa Tengah dan Jawa Timur yang memiliki pendapatan rendah, tetapi juga terjadi peningkatan pendapatan di Provinsi DKI Jakarta yang berkontribusi positif pada komponen income effect. Allocation effect dari masing-masing subgrup pada partisi ini relatif sangat kecil. Hal ini menunjukkan proporsi populasi yang relatif stabil pada periode ini juga membuat allocation effect relatif kecil. Dibandingkan dengan periode sebelumnya, terjadi peningkatan ketimpangan yang tinggi di Provinsi Jawa Timur. Hal ini ditunjukkan dari tingginya kontribusi provinsi ini pada komponen pure inequality effect. Provinsi Jawa Barat dan Jawa Tengah juga masih mengalami peningkatan ketimpangan. Kemungkinan peningkatan ketimpangan di dalam provinsi-provinsi ini dipicu oleh peningkatan harga BBM yang terjadi pada periode 2011-2014. Karena berdasarkan penelitian untuk periode 2005-2011oleh Utari dan S. Retni (2014) peningkatan harga BBM pada periode tersebut mengakibatkan terjadinya inflasi yang akan berdampak lebih buruk pada masyarakat berpenghasilan rendah. Ketiga provinsi ini merupakan provinsi dengan persentase penduduk tertinggi. Namun belum ada penelitian empiris apakah kenaikan harga BBM pada tahun 2011-2014 juga berdampak lebih buruk pada masyarakat miskin.

Tabel 12. Dekomposisi Dinamis Partisi Provinsi Tahun 2011-2014

\begin{tabular}{|cccrr|}
\hline \multicolumn{5}{c|}{ Proporsi perubahan $I_{0}=0,0329$} \\
\hline Subgrup & $\begin{array}{c}\text { Pure Inequality } \\
\text { Effect }\end{array}$ & $\begin{array}{c}\text { Allocation Effect } \\
\text { on Within Group }\end{array}$ & $\begin{array}{c}\text { Allocation Effect } \\
\text { on Between } \\
\text { Group }\end{array}$ & Income Effect \\
\hline Sumatera Utara & -0.0024 & -0.0005 & -0.0033 & -0.0038 \\
Sumatera Barat & -0.0012 & 0.0000 & 0.0000 & 0.0004
\end{tabular}




\begin{tabular}{|c|c|c|c|c|}
\hline \multicolumn{5}{|c|}{ Proporsi perubahan $I_{0}=0,0329$} \\
\hline Subgrup & $\begin{array}{c}\text { Pure Inequality } \\
\text { Effect }\end{array}$ & $\begin{array}{l}\text { Allocation Effect } \\
\text { on Within Group }\end{array}$ & $\begin{array}{c}\text { Allocation Effect } \\
\text { on Between } \\
\text { Group }\end{array}$ & Income Effect \\
\hline Riau & 0.0002 & 0.0005 & 0.0028 & 0.0036 \\
\hline Jambi & -0.0006 & 0.0001 & 0.0005 & -0.0002 \\
\hline Sumatera Selatan & 0.0014 & -0.0004 & -0.0017 & -0.0021 \\
\hline Bengkulu & -0.0016 & 0.0001 & 0.0003 & -0.0004 \\
\hline $\begin{array}{l}\text { Lampung } \\
\text { Kep. Bangka }\end{array}$ & -0.0025 & 0.0001 & 0.0004 & -0.0051 \\
\hline $\begin{array}{l}\text { Kep. Bangka } \\
\text { Belitung }\end{array}$ & 0.0000 & 0.0001 & 0.0007 & 0.0016 \\
\hline Kepulauan Riau & 0.0016 & 0.0001 & 0.0007 & 0.0067 \\
\hline DKI Jakarta & 0.0031 & 0.0002 & 0.0010 & 0.0461 \\
\hline Jawa Barat & 0.0053 & -0.0008 & -0.0033 & -0.0003 \\
\hline Jawa Tengah & 0.0045 & -0.0010 & -0.0049 & -0.0311 \\
\hline DI Yogyakarta & -0.0017 & 0.0001 & 0.0005 & -0.0001 \\
\hline Jawa Timur & 0.0166 & -0.0015 & -0.0071 & -0.0261 \\
\hline Banten & -0.0002 & 0.0010 & 0.0040 & 0.0103 \\
\hline Bali & 0.0024 & -0.0003 & -0.0013 & 0.0083 \\
\hline NTB & 0.0026 & 0.0008 & 0.0037 & -0.0037 \\
\hline NTT & 0.0009 & 0.0002 & 0.0013 & -0.0066 \\
\hline Kalimantan Barat & 0.0010 & 0.0003 & 0.0015 & -0.0002 \\
\hline Kalimantan & & & & \\
\hline Tengah & 0.0006 & 0.0002 & 0.0010 & 0.0013 \\
\hline Kalimantan & & & & \\
\hline Selatan & -0.0021 & 0.0002 & 0.0008 & 0.0015 \\
\hline Kalimantan & & & & \\
\hline Timur & -0.0001 & 0.0002 & 0.0011 & 0.0063 \\
\hline Sulawesi Utara & 0.0018 & -0.0001 & -0.0006 & 0.0000 \\
\hline Sulawesi Tengah & 0.0001 & 0.0001 & 0.0004 & -0.0010 \\
\hline Sulawesi Selatan & 0.0006 & -0.0001 & -0.0004 & -0.0029 \\
\hline Sulawesi & & & & \\
\hline Tenggara & -0.0005 & 0.0003 & 0.0012 & -0.0012 \\
\hline Gorontalo & 0.0007 & 0.0000 & 0.0000 & -0.0009 \\
\hline Maluku & -0.0013 & 0.0000 & 0.0000 & -0.0006 \\
\hline Maluku Utara & 0.0001 & 0.0001 & 0.0005 & -0.0005 \\
\hline Papua & -0.0032 & 0.0002 & 0.0008 & 0.0007 \\
\hline Total & 0.0261 & $\mathbf{0}$ & 0.0005 & $\mathbf{0}$ \\
\hline
\end{tabular}

Sumber : Perhitungan penulis dari data SUSENAS 2011 dan 2014

Pada partisi berdasarkan status pekerjaan, nilai komponen pure inequality effect lebih tinggi dari pada proporsi perubahan $I_{0}$. Pada periode ini terjadi sektorsektor informal lebih berkembang. Dilihat dari Tabel 13, peningkatan pendapatan rata-rata subgrup-subgrup pekerja informal memberikan kontribusi yang lebih besar pada komponen income effect. Peningkatan pendapatan pada subgrupsubgrup pekerja informal ini berkontribusi lebih besar dari pada peningkatan pendapatan pada subgrup-subgrup pekerja formal, sehingga menyebabkan semakin konvergennya pendapatan antara populasi dengan status pekerjaan kepala keluarga yang berbeda. Walaupun terjadi peningkatan pendapatan rata-rata dari subgrup-subgrup pekerja informal, terdapat penurunan proporsi populasi pada subgrup Berusaha Dibantu Buruh Tidak Tetap. Tingginya penurunan proporsi populasi pada subgrup Berusaha Dibantu Buruh Tidak Tetap berkontribusi paling besar pada komponen allocation effect. 
Walaupun terdapat nilai negatif pada income effect dan allocation effect, hal ini berlawanan dengan tren ketimpangan yang terjadi. Dengan kata lain baik income effect maupun allocation effect pada partisi status pekerjaan di periode ini tidak dapat menjelaskan perubahan ketimpangan yang terjadi. Peningkatan ketimpangan lebih dapat dijelaskan oleh komponen pure inequality effect. Pada periode ini terjadi peningkatan ketimpangan pada sebagian besar subgrup-subgrup pekerja informal maupun formal. Hal ini terlihat dari kontribusi positif dari sebagian besar subgup untuk komponen pure inequality effect.

Tabel 13. Dekomposisi Dinamis Partisi Status Pekerjaan Tahun 2011-2014

\begin{tabular}{|lcccr|}
\hline \multicolumn{4}{|c}{ Proporsi perubahan $I_{0}=0,0329$} & \\
\hline & $\begin{array}{c}\text { Pure } \\
\text { Subgrup }\end{array}$ & $\begin{array}{c}\text { Allocation } \\
\text { Effect on } \\
\text { Effect }\end{array}$ & $\begin{array}{c}\text { Allocation } \\
\text { Effect on } \\
\text { Between } \\
\text { Group }\end{array}$ & $\begin{array}{c}\text { Group } \\
\text { Income } \\
\text { Effect }\end{array}$ \\
\hline $\begin{array}{l}\text { Berusaha Sendiri } \\
\text { Berusaha Dibantu Buruh }\end{array}$ & 0.0160 & 0.0105 & 0.0512 & -0.0208 \\
Tidak Tetap & -0.0070 & -0.0172 & -0.0925 & -0.0446 \\
$\begin{array}{l}\text { Pekerja Bebas } \\
\text { Pekerja Tidak Dibayar }\end{array}$ & 0.0020 & 0.0035 & 0.0287 & -0.0509 \\
$\begin{array}{l}\text { Buruh/Karyawan/Pegawai } \\
\text { Berusaha Dibantu Buruh }\end{array}$ & 0.0012 & 0.0023 & 0.0109 & -0.0006 \\
$\begin{array}{l}\text { Dibayar } \\
\text { Total }\end{array}$ & 0.0274 & -0.0001 & -0.0004 & 0.0828 \\
\hline
\end{tabular}

Sumber : Perhitungan penulis dari data SUSENAS 2011 dan 2014

\section{KESIMPULAN}

Karakteristik populasi berdasarkan pendidikan, perbedaan lokasi kota-desa dan provinsi serta perbedaan status pekerjaan adalah kondisi yang sering dikaitkan dengan ketimpangan yang tinggi. Hal ini didasari karena pada pengelompokan populasi berdasarkan karakteristik-karakteristik tersebut menunjukkan perbedaan pendapatan yang tinggi. Berdasarkan hasil dekomposisi statis pada penelitian ini, pengelompokan populasi berdasarkan tingkat pendidikan kepala rumah tangga menunjukkan ketimpangan yang paling tinggi. Ini berarti terjadi ketimpangan pendapatan yang tinggi antar penduduk dengan tingkat pendidikan yang berbeda. Maka dari itu, kebijakan untuk penurunan ketimpangan sebaiknya lebih difokuskan pada populasi berdasarkan tingkat pendidikan yang berbeda.

Pada kelompok populasi berdasarkan tingkat pendidikan kepala rumah tangga, kelompok Tidak Berijazah, berijazah SD dan berijazah SMP adalah kelompok dengan jumlah populasi tertinggi tetapi memiliki pendapatan yang lebih rendah dari pada pendapatan rata-rata. Proporsi populasi pada kelompokkelompok tersebut sudah menunjukkan trend penurunan dan proporsi populasi dengan pendidikan kepala rumah tangga lebih tinggi juga sudah mengalami peningkatan. Hal ini mengindikasikan sudah terjadi peningkatan pendidikan kepala rumah tangga di Indonesia. Namun, penelitian ini menemukan bahwa penurunan proporsi populasi pada kelompok populasi dengan pendidikan kepala rumah tangga yang rendah tersebut tidak cukup berkontribusi untuk menurunkan ketimpangan. Oleh karena itu untuk mengurangi ketimpangan sebaiknya yang dilakukan adalah dengan mendorong peningkatan pendidikan masyarakat. Pemerintah sebaiknya membuat kebijakan untuk lebih mendukung agar pelajarpelajar SD dan SMP tidak putus sekolah. Masyarakat sebaiknya lebih didorong 
agar memiliki ijazah minimum SMA atau sederajat agar memiliki pendapatan tidak lebih rendah dari pendapatan rata-rata.

Penelitian ini juga menemukan bahwa pada partisi berdasarkan wilayah yaitu kota-desa dan provinsi, peningkatan ketimpangan yang terjadi pada periode 2005-2011 berasal dari peningkatan ketimpangan yang terjadi pada di masingmasing subgrup. Pada periode ini subgrup-subgrup dengan jumlah penduduk miskin yang tinggi mengalami peningkatan ketimpangan. Penelitian empiris yang telah dilakukan sebelumnya menunjukkan bahwa kenaikan harga BBM pada periode ini berdampak lebih buruk pada masyarakat berpenghasilan rendah, diduga ini lah yang menyebabkan peningkatan ketimpagan tersebut. Namun belum ada penelitian empiris terkait pengaruh peningkatan harga BBM pada periode 2011-2014 terhadap pendapatan masyarakat untuk periode tersebut.

Pada periode 2011-2014, terjadi peningkatan pendapatan populasi di perkotaan yang membuat semakin divergennya pendapatan antara masyarakat perkotaan dan pedesaan. Maka dari itu sebaiknya pemerintah menyusun kebijakan untuk pengembangan desa agar pendapatan rata-rata di desa dapat lebih meningkat. Di sisi lain perubahan proporsi populasi maupun perubahan pendapatan pada kelompok masyarakat berdasarkan provinsi maupun status pekerjaan kepala rumah tangga tidak dapat menjelaskan peningkatan ketimpangan yang terjadi. Walaupun besar ketimpangan yang terjadi pada populasi berdasarkan kedua karakteristik ini cukup tinggi, tetapi perubahannya ketimpangan lebih diakibatkan oleh kondisi ketimpangan yang meningkat pada kelompok populasi di provinsi yang sama maupun status pekerjaan yang sama.

\section{DAFTAR RUJUKAN}

ADB. (2012). Key Indicators for Asia and the Pasific . Manila: ADB.

Aji, P. (2015). Summary of Indonesia's Poverty Analysis. Jakarta: ADB.

Akita, T., \& Alisjahbana, A. (2002). Regional Income Inequality in Indonesia and the Initial Impact of the Economic Crisis . Bulletin of Indonesian Economic Studies, , 38, 201-222.

Akita, T., \& Hermawan, A. (2000). The Sources of Industrial Growth in Indonesia, 1985 95: An Input-Output Analysis . ASEAN Economic Bulletin, 17, 270-284.

Akita, T., \& Miyata, S. (2007). Urbanization, educational expansion, and expenditures inequality in Indonesia in 1996, 1999, and 2002. Washington DC: International Food Policy Research Institute (IFPRI).

Akita, T., \& R.A, L. (1995). Interregional Inequalities in Indonesia: A Sectoral Decomposition Analysis for 1975-92 . Bulletin of Indonesian Economic Studies, , 31, 61-81.

Akita, T., \& R.A, L. (35). Spatial Patterns of Expenditure Inequalities in Indonesia: 1987, 1990, and 1993 . Bulletin of Indonesian Economic Studies, 65-88.

Arsyad, L. (2004). Ekonomi Pembangunan. Yogyakarta: STIE YKPN.

Cowell, F., \& Jenkins, S. (1995). How much inequality can we explain? A methodology and an. Economic Journal, 421-430.

Dartanto, T. (2013). Why is growth less inclusive in Indonesia? Munich Personal RePEc Archive. 
Dartanto, T., \& Usman. (2015). Impacts of Policies and Shocks on Inequality in Indonesia. FGD Bappenas. Jakarta: LPEM UI.

Dinca-Panaitescu, M., \& Walks, A. (2015). Income Inequality, Income Polarization, and Poverty. Toronto: Creative Common.

Ferreira, F. H., G.Leitte, P., \& Litchfield, J. A. (2007). The Rise and Fall of Brazillian Inequality: 1981-2004. Macroeconomic Dynamics.

Ferreira, F., \& Litchfield, J. (2001). Education or Inflation?: The micro and macro economics of the Brazilian Income Distribution during 1981-1995. Cuardenos de Economia 38(141), 209-238.

Haughton, J., \& Khandker, S. (2009). Handbook on Poverty and Inequality. Washington DC: World Bank Publication.

IMF. (2015). Gender and Income Inequality. www.imf.org.

Iryanti, R. (2014). Kemiskinan dan Ketimpangan di Indonesia : Permasalahan dan Tantangan. Kementrian PPN/ Bapenas. Yogyakarta: Kementrian PPN/ Bapenas.

Jurkatis, S., \& Strehl, W. (2013). Dos and Dont's of Gini Decomposition. Berlin: Berlin Doktoral Program in Economics and Management Science.

Kepala Bappenas. (2012). Rasio Gini di Indonesia dalam Lima Tahun Terakhir. Jakarta: Kementrian Bappenas.

Lelkes, O., Medgyesi, M., \& Toth, I. G. (2009). European Inequalities: Social Inclusion and Income Distribution in the European Union. Dalam T. Ward, O. Lelkes, H. Sutherland, \& I. G. Tóth, European Inequalities :Social Inclusiom and Income Dsitribution in the European Union (hal. 46-67). Budapest: TARKI Social Research Institue Inc.

Litchfield, J. A. (1999). Inequality : Methods and Tools. World Bank's Web Site on Inequality, Poverty, and Socio-economic Performance.

Mazumdar, D., \& Sarkar, S. (2013). Manufacturing Enterprise in Asia. Oxon: Routledge.

Mockherjee, D., \& Shorrocks, S. (1982). A Decomposition Analysis of Trends in Income Inequality. Economic Journal, 886-902.

Muniz, J. O. (209). Statistic and Dynamic Decomposition of Income Inequality in Brazil. XXVVI IUSSP International Population Conference. Marrakech.

Nuraliyah. (2009). DEKOMPOSISI KETIMPANGAN PENDAPATAN DI INDONESIA PASCA KRISIS (TAHUN 1999-2005). IPB. IPB.

OECD. (2011). Divided We Stand Why Inequality Keeps Rising. OECD Publishing.

Romo, V. C. (2003). Decomposition Methods in Demography. Amsterdam: Rozenberg.

Scanlon, T. (2014, March 6). The 4 Biggest Reasons Why Inequality is Bad for Society. Dipetik October 15, 2015, dari ideas.ted.com: http://ideas.ted.com/the-4-biggest-reasons-why-inequality-is-bad-forsociety/

Sjafrizal. (2012). Ekonomi Wilayah dan Perkotaan. Jakarta: PT Rajagrafindo.

Sukirno, S. (2001). Pengantar Teori Makroekonomi. Jakarta: Raja Grafindo.

Utari, G. D., \& S, R. C. (2014). Growth \& Inequality in Indonesia : Does Kuznets Curve Hold? Dipetik 07 1, 2016, dari Econpapers: http://econpapers.repec.org 
Vega, M. c., \& Urrutia, A. M. (2003). A New Factorial Decomposition for The Atkinson Measure. Economics Bulletin, 1-12.

World Bank. (2015, 12 08). Indonesia Rising Divide. The World Bank. 